\title{
各種の地震動に対する 累積損傷度法による液状化判定法の適用性
}

\author{
井澤 淳 1 ・田上 和也 2 ・室野 剛隆 3 \\ 1正会員（公財）鉄道総合技術研究所（T185-8540 東京都国分寺市光町2-8-38） \\ E-mail:izawa@rtri.or.jp \\ 2正会員 ジェイアール東海コンサルタンツ惏（テ 450-0002 愛知県名古屋市中村区名駅5-33-10） \\ E-mail:k-tanoue@jrcc.co.jp \\ 3正会員 （公財）鉄道総合技術研究所（T185-8540 東京都国分寺市光町2-8-38） \\ E-mail:murono@rtri.or.jp
}

\begin{abstract}
本稿では，各種の地震動に対する累積損傷度法による液状化判定の適用性について検討することを目的 とし, 有効応力解析との比較を行っている. まず有効応力解析により, 低加速度・長継続時間地震動であ っても大振幅の直下型地震と同等の液状化が発生寸る可能性があることを示した。このような液状化現象 を累積損傷度法により評価する場合は, 多繰り返し部の液状化強度曲線を精度良く評価する必要があるこ とを示した. また, 累積損傷度法によって液状化に至るまでの地盤に作用寸るせん断灾力比をある程度評 価できること，過剩間隙水圧の上昇傾向を累積損傷度Dの増加傾向で評価できることが分かった．ただし， 過剩間隙水圧の上昇による剛性低下を考慮していないため, 液状化発生後のせん断応力を過大に算定して しまい，過剩に液状化する判定を与えてしまう可能性があることも示した。
\end{abstract}

Key Words : Soil liquefaction, Accumulated damage parameter, Effective stress analysis, Long period and long duration earthquake

\section{1. はじめに}

筆者ら ${ }^{12 / 2}$ は巨大地震発生時に危惧されている長継続時 間地震動に対する地盤の液状化問題について検討を行っ てきたが，2011年東北地方太平洋地震における東京湾沿 岸において, 低加速度でありながら地震動が長時間継続 することによって，大規模な液状化が広範囲で発生した ことが報告されている，したがって，液状化判定におい て地震動の特性，特に継続時間の影響を適切に評価する ことが求められる.

道路橋示方書では累積損傷度法を用いて地震動の繰り 返し特性による補正係数 $\mathrm{C}_{\mathrm{W}}$ 算出している3゙ 。これは 直下型地震動のような振幅は大きいものの繰り返し回数 の少ない地震動に対して, 繰返し回数20回に対寸る液状 化強度 $\mathrm{R}_{20}$ よりも液状化強度を増加させる係数である.

一方で, 継続時間の長く振幅は比較てき小さい海溝型地 震に対しては， $\mathrm{C}_{\mathrm{w}}=1$ ，すなわち $\mathrm{R}_{20}$ と同程度であるとし ている．なお，この検討に用いている液状化強度曲線 (液状化強度比と繰返し回数の関係) は東ら ${ }^{4}$ の豊浦砂 の実験結果を用いている。八代らうは道路橋示方書に示
されている地震動よりもさらに継続時間が長くなると考 えられる想定東海地震，想定東南海地震に対して，同様 の検討を行っている. その結果，東海・東南海地震のよ うな長継続時間地震動に対しては $\mathrm{C}_{\mathrm{w}}=0.9$ 程度を用いて, 液状化強度を1割程度低減させる必要があることを提案 している. 一方, 吉田らけは2種類の海溝型長継続時間地 震動を用いて236の地盤に対する有効応力解析結果と液 状化判定の比較を行い, 海溝型長継続時間地震動に対し ては $\mathrm{C}_{\mathrm{w}}=0.5$ を提案している.

鉄道構造物等設計標準・同解説 而震設計》では，L2地 震動に対してこのような $\mathrm{C}_{\mathrm{w}}$ を定義することなく, 対象 地盤の液状化強度曲線を用いて設計地震動に対して累積 損傷度法を用いた液状化判定を行うことで，地震動の特 性を評価することとなっている，本稿では，低加速度・ 長継続時間地震動のような特徵的な地震動に対する累積 損傷度法の適用性を検討することを目的とし，有効応力 解析と累積損傷度法による液状化判定の比較を行ってい る. 特に既往の研究であまり評価されていない液状化強 度曲線の形状の影響や作用の妥当性について着目寸る. 
表-1 地盤特性および解析パラメータ

\begin{tabular}{|c|c|c|c|c|c|c|c|c|c|c|c|c|c|c|c|}
\hline & & \multirow{2}{*}{$\begin{array}{c}\text { 深度 } \\
(\mathrm{m})\end{array}$} & \multirow{2}{*}{$\begin{array}{c}\gamma \\
\left(\mathrm{kN} / \mathrm{m}^{3}\right)\end{array}$} & \multirow{2}{*}{$\begin{array}{c}\mathrm{V}_{\mathrm{s}} \\
(\mathrm{m} / \mathrm{s})\end{array}$} & \multirow[b]{2}{*}{$v$} & \multirow{2}{*}{$\mathrm{h}_{\max }$} & \multirow{2}{*}{$\begin{array}{c}\mathrm{G}_{\mathrm{m} 0} \\
\left(\mathrm{kN} / \mathrm{m}^{2}\right)\end{array}$} & \multirow{2}{*}{$\begin{array}{c}\mathrm{K}_{\mathrm{m} 0} \\
\left(\mathrm{kN} / \mathrm{m}^{2}\right)\end{array}$} & \multirow{2}{*}{$\begin{array}{l}\phi \\
\left(^{\circ}\right)\end{array}$} & \multicolumn{6}{|c|}{ 液状化パラメータ } \\
\hline & & & & & & & & & & $\phi_{\mathrm{p}}\left({ }^{\circ}\right)$ & $\mathrm{S}_{1}$ & $\mathrm{w}_{1}$ & $\mathrm{p}_{1}$ & $\mathrm{p}_{2}$ & $\mathrm{c}_{1}$ \\
\hline & まさ土層(1) & 3.8 & 20.6 & 100 & 0.435 & 0.24 & 21020 & 154780 & 30 & - & - & - & - & - & - \\
\hline \multirow{8}{*}{$\begin{array}{l}\text { 液 } \\
\text { 状 } \\
\text { 化 } \\
\text { 層 }\end{array}$} & まさ土層(2) & 6.6 & 20.6 & 170 & 0.435 & 0.24 & 60749 & 447314 & 30 & 28 & 0.005 & 33.1 & 0.5 & 1.27 & 1.0 \\
\hline & まさ土層(3) & 9.5 & 20.6 & 160 & 0.443 & 0.24 & 53812 & 451939 & 30 & 28 & 0.005 & 33.1 & 0.5 & 1.27 & 1.0 \\
\hline & まさ土層(4) & 14.8 & 20.6 & 200 & 0.486 & 0.24 & 84082 & 2972146 & 30 & 28 & 0.005 & 26.0 & 0.5 & 1.22 & 1.5 \\
\hline & 沖積粘性土 & 20.7 & 16.7 & 160 & 0.486 & 0.24 & 53812 & 1902173 & 30 & - & - & - & - & - & - \\
\hline & 洪積互層 & 26.7 & 18.6 & 200 & 0.492 & 0.24 & 68041 & 4378001 & 30 & - & - & - & - & - & - \\
\hline & 洪積互層 & 28.0 & 20.6 & 240 & 0.489 & 0.24 & 109558 & 4958575 & 30 & - & - & - & - & - & - \\
\hline & 洪積互層 & 30.7 & 20.6 & 210 & 0.487 & 0.24 & 92700 & 3453182 & 30 & - & - & - & - & - & - \\
\hline & 洪積互層 & 33.7 & 20.6 & 270 & 0.488 & 0.24 & 153239 & 6281284 & 30 & - & - & - & - & - & - \\
\hline
\end{tabular}

表-2 入力加速度の特性

\begin{tabular}{lcccc}
\hline & $\begin{array}{c}\text { 最大加速度 } \\
(\mathrm{Gal})\end{array}$ & $\begin{array}{c}\text { 浦安波 } \\
\text { との比 }\end{array}$ & $\begin{array}{c}\text { 加速度パワー } \\
\left(\mathrm{cm}^{3} / \mathrm{s}^{2}\right)\end{array}$ & $\begin{array}{c}\text { 浦安波 } \\
\text { との比 }\end{array}$ \\
\hline \hline 神戸波 & -818.8 & 5.23 & 525130 & 5.10 \\
\hline 神戸補正波 & -156.6 & 1.00 & 19215 & 0.19 \\
\hline 苫小牧補正波 & -156.6 & 1.00 & 100260 & 0.97 \\
\hline 浦安波 & 156.6 & 1.00 & 102964 & 1.00 \\
\hline
\end{tabular}

\section{2. 解析概要および入力地震波}

有効応力解析にはTowhata and Ishihra)のマルチスプリン グモデルと lai et al. ${ }^{9}$ の過剰間隙水圧モデルを組み込んだ モデルを採用し，一次元の地盤応答解析を行った。なお， 本解析は非排水条件とし，過剰間隙水圧の消散は考慮し ていない．解析対象は兵庫県南部地震で大きな液状化被 害が生じた深江浜とし，三輪ら ${ }^{10)}$ の検討を参考に表-1 に示すパラメータを設定した.

入力地震動としては，長継続時間地震動の例として 2011年東北地方太平洋沖地震のK-NET浦安EW成分（以 後，浦安波）と，2003年十勝沖地震におけるK-NET苫小 牧EW成分の最大加速度が浦安波と等しくなるように調 整して用いた（以後，苫小牧補正波）。典型的な直下型 地震動としては，1995年兵庫県南部地震における神戸海 洋気象台記録のNS成分を用いた（以後，神戸波）。神 戸波については最大加速度が浦安波と等しくなるように 調整した波についても検討した（以後，神戸補正波）.

表-2にそれぞれの地震動の最大加速度と加速度パワーを 示す。神戸波は最大加速度, 加速度パワーともに浦安波 の5倍以上である．最大加速度を調整した苫小牧補正波 は，加速度パワーについても浦安波と同等となっている. 図-1および2に入力波の時刻歴とフーリエ振幅スペクト ルを示す。浦安波と苫小牧波を比べると，苫小牧波では 3 4秒程度のやや長周期の成分が卓越しているのに対し て, 浦安波の卓越周期は1秒程度であったことが分かる. 今回の検討では地表面での観測記録をそのまま基盤に入 力しているが，それぞれの地震動を受けた場合の相対的

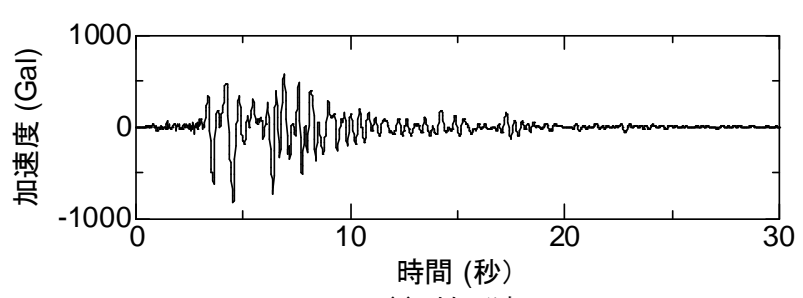

(a) 神戸波

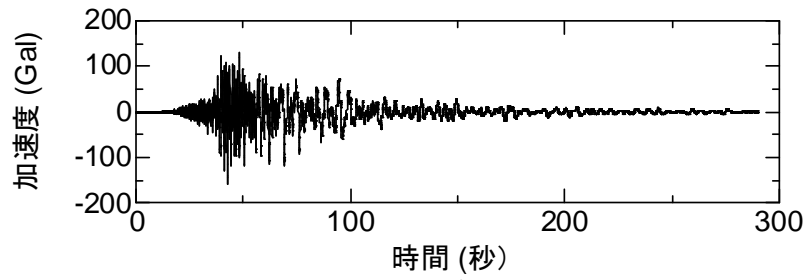

(b) 苫小牧補正波

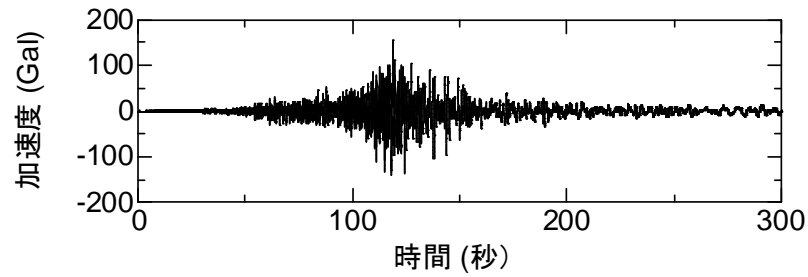

(c) 浦安波

図-1 入力地震動時刻歴

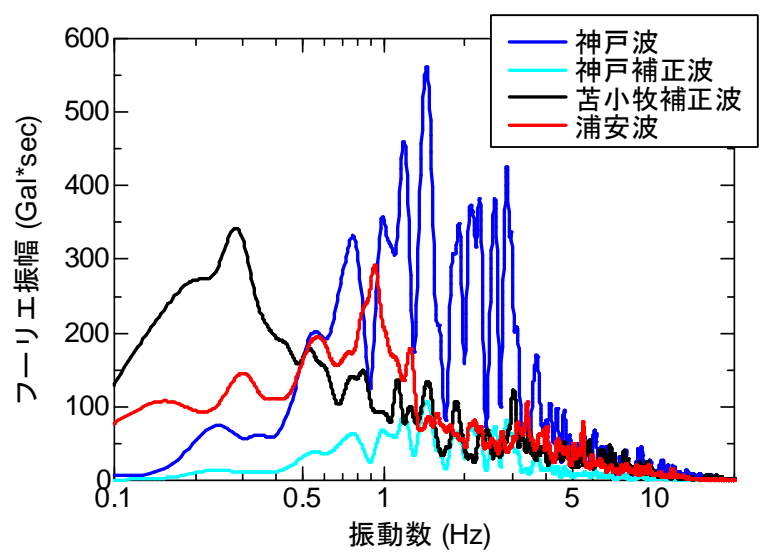

図-2 入力地震動のフーリ振幅スペクトル

な比較として検討を行っている。

なお， $F_{\mathrm{L}}$ 法では地盤内に作用するせん断応力と液状化 強度の比較から液状化の判定を行う。通常，地盤内に作 

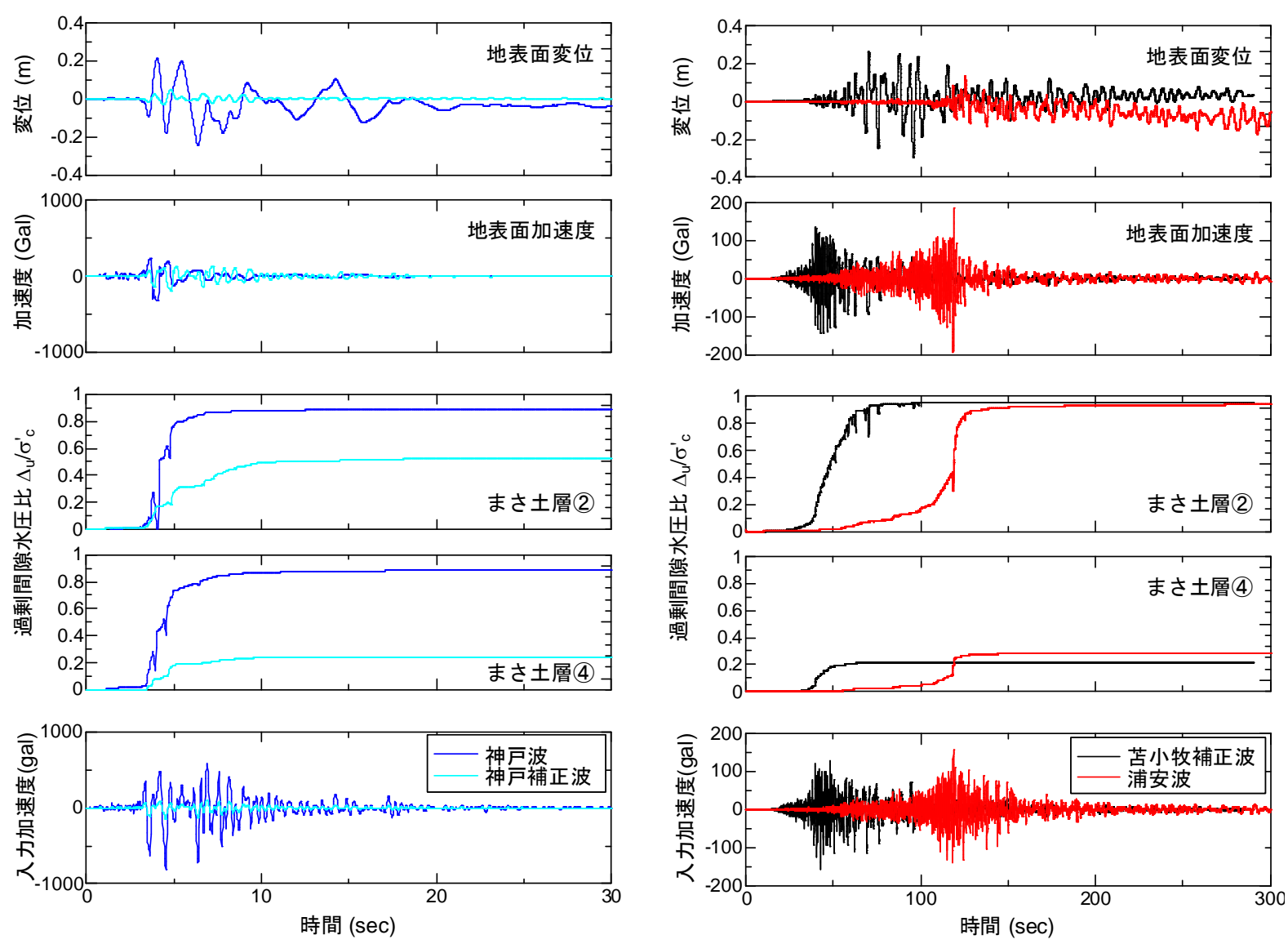

(a) 神戸波・神戸補正波

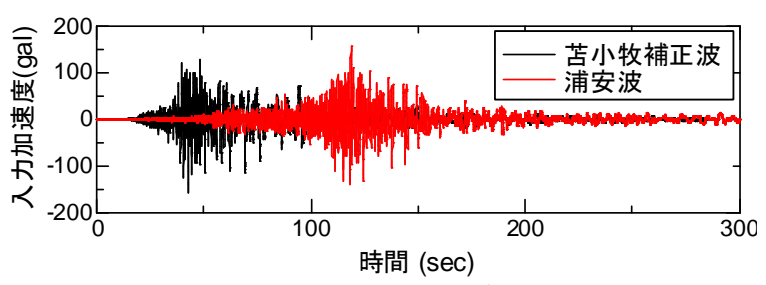

(b) 浦安波・苫小牧補正波

図-3 過剩間隙水圧比・地表面加速度・地表面変位の時刻歴

用するせん断応力は地表面の加速度のピーク值から算定 することが多いが，パルス的な加速度は地盤内のせん断 応力に影響を与えないなどの問題が指摘されている。 そ のため, 速度を指標としたせん断応力の算定方法例えば11 や入力地震動のうち地盤の塑性変形に費やされるエネル ギーを指標として外力を評価する方法12などが提案され ている. したがって, 最大加速度を調整した地震動を用 いる事が適切でない可能性もあるたただし，本論文では 鉄道設計標準に示寸累積損傷度法を用いた液状化判定と 有効応力解析の比較検討を目的としており, 液状化判定 におけるせん断応力比の算定には地表面加速度を用いて いるため, 最大加速度を調整した地震動を用いて比較を 行った.

\section{3. 有効応力解析結果}

図-3 にまさ土層(2)と(4)における過剩間隙水圧比 $\Delta \mathrm{u} / \sigma_{c}^{\prime}$, 地表面での応答加速度および変位の時刻歴を入力加速度 とともに示寸．まさ土層(2)着目寸ると，浦安波と苫小 牧補正波を入力した場合, 加速度および加速度パワーが 5 倍以上の神戸波を入力した場合と同程度以上の過剩間 隙水圧比 $\Delta \mathrm{u} / \sigma_{\mathrm{c}}$ を生じていることが分かる．また浦安波
と同じ最大加速度を有していても, 神戸補正波のケース では $\Delta \mathrm{u} / \sigma_{\mathrm{c}}=0.5$ 程度までしか至っていない，一方，まさ 土層(4)においては，神戸波では $\Delta \mathrm{w} / \sigma_{\mathrm{c}}^{\prime}=0.95$ 以上まで上昇 したのに対して，浦安波および苫小牧補正波では 0.3 程 度までしか上がっておらず，長継続時間地震動に対して 液状化抵抗の大きい地盤であったと考えられる. この層 は試験から得られた液状化強度曲線とのフィッティング によるパラメータ設定から， c 1 が他の層と比べて 1.5 倍 大きく設定してある. $\mathrm{c}_{1}$ は間隙水圧の上昇に及ぼす弾性 せん断仕事の寄与度を調整するパラメータであり, 大き な值ほど間隙水圧の上昇は小さくなる．したがって， $c_{1}$ の大きいまさ土層(4)で泇速度振幅の小さい領域におい てあまり過剩間隙水圧が上昇しなかったと考えられる. 逆に小さなひずみ振幅で過剩間隙水圧が蓄積しやすい地 盤では, 長継続時間地震動を受けた場合の地盤の液状化 に注意する必要があると考えられる。

地表面での応答加速度および変位を見ると, いずれの ケースにおいても液状化に至った後で応答加速度は小さ くなり，水平変位は堌幅する. 特に苫小牧波では液状化 後の70～100秒の間に大きな変位の増幅が見られる.こ れは液状化による岡性低下により固有周期の長周期化し た地盤が，苫小牧波の後半に見られる長周期成分の地震 動により増幅したものと考えられる. 一方で，図-2に示 
すスペクトルからも分かるように，浦安波ではそれほど 長周期成分が卓越していないため，苫小牧波のような液 状化後の変位の大きな増幅は見られなかった。

\section{4. 累積損傷度法を用いた液状化判定}

\section{(1) 累積損傷度法による液状化判定}

有効応力解析から，低加速度であっても継続時間が長 くなることで夜状化に至る可能性があることが分かった 簡易的に地震動の特性を評価できる液状化判定手法とし ては累積損傷度法が挙げられる。ここでは，鉄道構造物 等設計標準・同解説 而震設計に準拠した累積損傷度法 による液状化判定を行い，有効応力解析結果を比較する ことで，長継続時間地震動に対する累積損傷度法の適用 性を評価する。

対象地盤のまさ土層の液状化強度比 $\mathrm{R}_{20}$ については, $\mathrm{D}_{50}=1.0 \mathrm{~mm} ， \mathrm{Fc}=15 \%$ とし，N值はまさ土層(2)〜(3)におい てそれぞれ10，12，16として算定し，それぞれ $\mathrm{R}_{20}=0.25$, $0.24,0.25 を$ 得た。

繰り返し回数iに対寸る液状化強度 $\mathrm{R}_{\mathrm{i}}$ は以下の式から算 定する。ここで相対密度Drは上記のN值から換算した值 を用いている。

i) $\mathrm{N}_{\mathrm{c}} \leqq 20$

$$
R_{(i)}=R_{20}\left(\frac{N c}{20}\right)^{-1.35 \exp (-3.64+0.037 D r)}
$$

ii) $\mathrm{N}_{\mathrm{c}}>20$

$$
R_{(i)}=R_{20}\left(\frac{N c}{20}\right)^{-0.23}
$$

一方で, ゼロクロッシングによる地表面波のピーク加速 度から式(3)(4)より, せん断応力比波列を求める. ここ で，神戸波・神戸補正波は式(3)から，苫小牧補正波・ 浦安波は式(4)から求めた。

$$
\begin{aligned}
& L=(1.0-0.015 z) \frac{a}{g} \frac{\sigma_{v}^{\prime}}{\sigma_{v}} \quad(\text { 直下型 }) \\
& L=(1.0-0.005 z) \frac{a}{g} \frac{\sigma_{v}^{\prime}}{\sigma_{v}} \quad(\text { 海溝型 })
\end{aligned}
$$

ここで $\mathrm{L}$ : 最大せん断応力比, $\mathrm{z}$ : 検討寸る位置 $(\mathrm{m}), \mathrm{a}$ : 地表面ピーク加速度 $(\mathrm{Gal}), \mathrm{g}$ : 重力加速度 $(\mathrm{Gal}), \sigma_{\mathrm{v}}$ : 全上載圧 $\left(\mathrm{kN} / \mathrm{m}^{2}\right) ， \sigma_{\mathrm{v}}^{\prime}$ : 有効上載圧 $\left(\mathrm{kN} / \mathrm{m}^{2}\right)$ である. Lと Rから対応する繰り返し回数 Ncを算出し, 式(5)よ り累積損傷度 Dを算出する。
表-3 累積損傷度法による液状化判定結果

神戸波

\begin{tabular}{ccccccc}
\hline & $\mathrm{R}_{20}$ & $\mathrm{R}_{\mathrm{L}}$ & $\mathrm{R}_{\mathrm{L}} \mathrm{R}_{20}$ & $\mathrm{~L}$ & $\mathrm{~F}_{\mathrm{L}}$ & $\Delta \mathrm{P}_{\mathrm{L}}$ \\
\hline \hline まさ士層(2) & 0.25 & 0.386 & 1.54 & 1.580 & 0.244 & 15.4 \\
\hline まさ士層(3) & 0.24 & 0.382 & 1.59 & 1.557 & 0.245 & 13.3 \\
\hline まさ士層(4) & 0.25 & 0.408 & 1.63 & 1.524 & 0.267 & 15.2 \\
\hline & & & & & $\mathrm{P}_{\mathrm{L}}=$ & 44.0 \\
\hline
\end{tabular}

神戸補正波

\begin{tabular}{ccccccc}
\hline & $\mathrm{R}_{20}$ & $\mathrm{R}_{\mathrm{L}}$ & $\mathrm{R}_{\mathrm{L}} \mathrm{R}_{20}$ & $\mathrm{~L}$ & $\mathrm{~F}_{\mathrm{L}}$ & $\Delta \mathrm{P}_{\mathrm{L}}$ \\
\hline \hline まさ士層(2) & 0.25 & 0.386 & 1.54 & 0.302 & 1.28 & 0.00 \\
\hline まさ士層(3) & 0.24 & 0.382 & 1.59 & 0.298 & 1.28 & 0.00 \\
\hline まさ士層(4) & 0.25 & 0.408 & 1.63 & 0.291 & 1.40 & 0.00 \\
\hline & & & & & $\mathrm{P}_{\mathrm{L}}=$ & 0.00 \\
\hline
\end{tabular}

苫小牧補正波

\begin{tabular}{ccccccc}
\hline & $\mathrm{R}_{20}$ & $\mathrm{R}_{\mathrm{L}}$ & $\mathrm{R}_{\mathrm{L}} / \mathrm{R}_{20}$ & $\mathrm{~L}$ & $\mathrm{~F}_{\mathrm{L}}$ & $\Delta \mathrm{P}_{\mathrm{L}}$ \\
\hline \hline まさ士層(2) & 0.25 & 0.267 & 1.07 & 0.286 & 0.934 & 1.34 \\
\hline まさ士層(3) & 0.24 & 0.261 & 1.09 & 0.273 & 0.957 & 0.762 \\
\hline まさ士層(4) & 0.25 & 0.268 & 1.07 & 0.254 & 1.057 & 0.000 \\
\hline & & & & & $\mathrm{P}_{\mathrm{L}}=$ & 2.10 \\
\hline
\end{tabular}

浦安波

\begin{tabular}{ccccccc}
\hline & $\mathrm{R}_{20}$ & $\mathrm{R}_{\mathrm{L}}$ & $\mathrm{R}_{\mathrm{L}} \mathrm{R}_{20}$ & $\mathrm{~L}$ & $\mathrm{~F}_{\mathrm{L}}$ & $\Delta \mathrm{P}_{\mathrm{L}}$ \\
\hline \hline まさ士層(2) & 0.25 & 0.269 & 1.08 & 0.286 & 0.940 & 1.22 \\
\hline まさ士層(3) & 0.24 & 0.263 & 1.10 & 0.273 & 0.962 & 0.663 \\
\hline まさ士層(4) & 0.25 & 0.270 & 1.08 & 0.254 & 1.06 & 0.00 \\
\hline & & & & & $\mathrm{P}_{\mathrm{L}}=$ & 1.88 \\
\hline
\end{tabular}

$$
D=\sum \frac{1}{2 N c}
$$

$\mathrm{D}=1$ で液状化が発生するとし，D=1 よなるようにせん断 応力比波列を補正し, 最大せん断応力比を累積損傷度法 により補正した液状化強度比 $\mathrm{R}_{\mathrm{D}}$ とする. 最後に異方応 力状態を考慮して, 式(6)より液状化強度比 $\mathrm{R}_{\mathrm{L}}$ 算出す る. 今回は $K_{0}=0.5$ としている.

$$
R_{L}=\frac{1+2 K_{0}}{3} R_{D}
$$

\section{（2）累積損傷度法による液状化判定結果}

表-3に各入力地震動に対する液状化判定結果を示す. 神戸波を入力した場合, すべての層が $\mathrm{F}_{\mathrm{L}}=1$ を下回り， $\mathrm{P}_{\mathrm{L}}=44.0$ と激しく液状化する地盤と判定される. 神戸波の 振幅を低下させた神戸補正波の場合，地震動の経時特性 は同じため, 算定される $R_{L}$ は等しいものの, 作用は $1 / 5$ 程度であるため $\mathrm{F}_{\mathrm{L}}=1$ を下回る層はないと判定される. こ こで, $\mathrm{R}_{\mathrm{L}} / \mathrm{R}_{20}$ は道路橋示方書における地震動の繰り返し 特性による補正係数 $\mathrm{C}_{\mathrm{w}}$ に相当する值である. 道路橋示 方書では $0.1<\mathrm{R}_{\mathrm{L}}\left(=\mathrm{R}_{20}\right) \leqq 0.4$ において $\mathrm{C}_{\mathrm{w}}=3.3 \mathrm{R}_{\mathrm{L}}+0.67$ を定めて おり， $\mathrm{R}_{20}=0.25$ とすると $\mathrm{C}_{\mathrm{W}}=1.495$ となる. 今回行った判

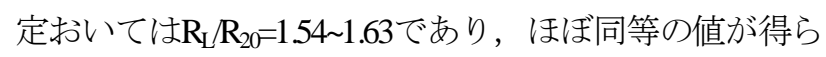
れている. 


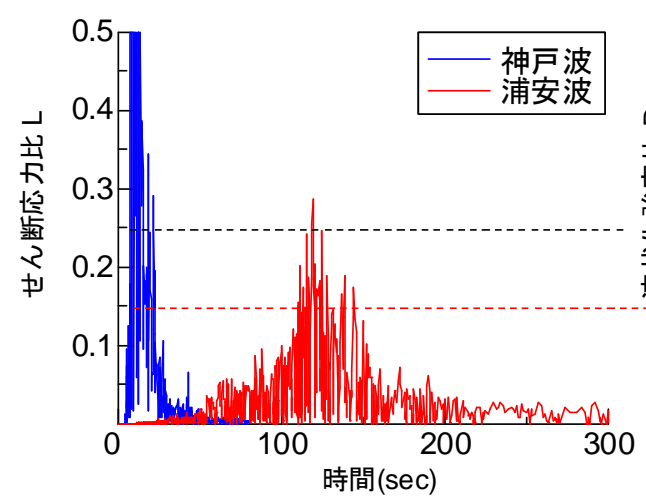

(b) せん断応力比時刻歴

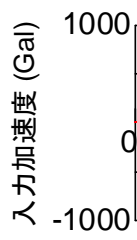

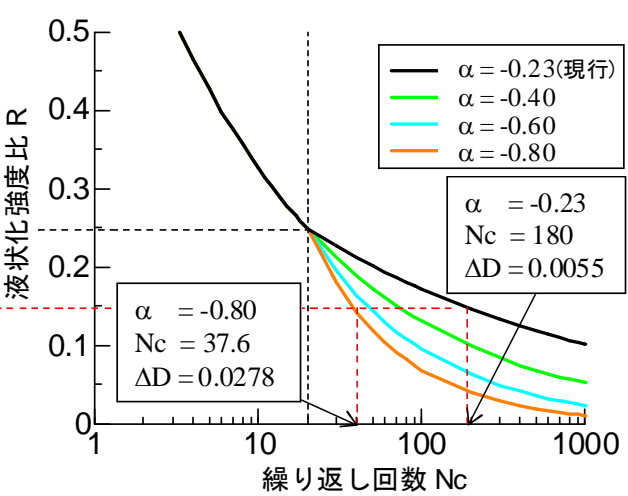

(c) 液状化強度曲線

図-4まさ土層(2)における浦安波および神戸波に対する入力加速度・せん断応力比時刻歴と いくつかの係数 $\alpha$ 対する液状化強度比

表-4 多繰り返し領域の液状化強度曲線を変えた場合の累積損傷度法による液状化判定結果

\begin{tabular}{|c|c|c|c|c|c|c|c|c|c|}
\hline \multirow{2}{*}{ 係数 $\alpha$} & & \multicolumn{4}{|c|}{ 浦安波 } & \multicolumn{4}{|c|}{$\begin{array}{l}\text { 神戸波 } \\
\end{array}$} \\
\hline & & $\mathrm{R}_{\mathrm{L}}$ & $\mathrm{F}_{\mathrm{L}}$ & $\Delta \mathrm{P}_{\mathrm{L}}$ & $\mathrm{P}_{\mathrm{L}}$ & $\mathrm{R}_{\mathrm{L}}$ & $\mathrm{F}_{\mathrm{L}}$ & $\Delta \mathrm{P}_{\mathrm{L}}$ & $\mathrm{P}_{\mathrm{L}}$ \\
\hline \multirow{3}{*}{$\begin{array}{c}-0.23 \\
\text { (現行) }\end{array}$} & "まさ土層(2) & 0.269 & 0.940 & 1.220 & & 0.386 & 0.244 & 15.4 & \\
\hline & まさ土層(3) & 0.263 & 0.962 & 0.663 & & 0.382 & 0.245 & 13.3 & \\
\hline & まさ土層(4) & 0.270 & 1.06 & 0.000 & 1.88 & 0.407 & 0.267 & 15.2 & 43.9 \\
\hline \multirow[t]{3}{*}{-0.40} & まさ土層(2) & 0.228 & 0.797 & 4.15 & & 0.372 & 0.236 & 15.6 & \\
\hline & まさ土層(3) & 0.222 & 0.815 & 3.27 & & 0.368 & 0.236 & 13.5 & \\
\hline & まさ土層(4) & 0.227 & 0.896 & 2.17 & 9.59 & 0.391 & 0.257 & 15.5 & 44.6 \\
\hline \multirow[t]{3}{*}{-0.60} & まさ土層(2) & 0.169 & 0.592 & 8.33 & & 0.352 & 0.223 & 15.8 & \\
\hline & まさ土層(3) & 0.165 & 0.603 & 7.00 & & 0.347 & 0.223 & 13.7 & \\
\hline & まさ土層(4) & 0.168 & 0.661 & 7.04 & 22.4 & 0.368 & 0.241 & 15.8 & 45.3 \\
\hline \multirow[t]{3}{*}{-0.80} & まさ土層(2) & 0.113 & 0.395 & 12.3 & & 0.325 & 0.205 & 16.2 & \\
\hline & まさ土層(3) & 0.110 & 0.403 & 10.5 & & 0.320 & 0.206 & 14.0 & \\
\hline & まさ土層(4) & 0.112 & 0.441 & 11.6 & 34.5 & 0.337 & 0.221 & 16.2 & 46.4 \\
\hline
\end{tabular}

一方，低加速度・長継続時間地震動である苫小牧補正 波と浦安波を入力した場合は，まさ土層(2)(3において $\mathrm{F}_{\mathrm{L}}=1$ を下回るものの，1程度である． $\mathrm{P}_{\mathrm{L}}$ 程度であり， 液状化の可能性の低い地盤と判定される. 苫小牧補正波, 浦安波を入力した場合の有効応力解析では，まさ土層(2) (3)で神戸波を入力した場合よりも大きな過剩間隙水圧が 発生しており，同等以上の液状化程度であったと考えら れる. 三輪ら ${ }^{10}$ の検討から，今回行った有効応力解析に おけるモデル化により，実際の液状化現象をよく再現出 来ていることが確認されている。したがって，今回の有 効応力解析結果がより現実に近い現象を評価していると した場合，現在の累積損傷度法の体系では低加速度・長 継続時間地震動に対する液状化の危険性を適切に評価で きていないと考えられる.

\section{(3) 液状化強度曲線の影響}

図-4に浦安波および神戸波の加速度時刻歴，土層(2)の せん断応力比と液状化強度曲線をまとめた. 図-4(c)に 黒の実線で示した液状化強度曲線は式(1)(2)から求まる 液状化強度曲線であるが，浦安波のせん断応力比のほと んどは繰り返し回数20回以上の領域に入っていることが 分かる。つまり，浦安波の様な低加速度・長継続時間地 震動に対する液状化判定においては，式(2)から求まる 多繰り返し領域での液状化強度が大きく影響すると考え られる。

式(2)から求まる $\mathrm{N}>20$ での液状化強度曲線の形状は， 0.23 という係数（以降 $\alpha$ とする）で決定される. そこで, $\alpha=-0.23,-0.4,-0.6,-0.8$ として液状化強度曲線を定義し て液状化判定を行い，多繰り返し領域の液状化強度が液 状化判定に与える影響の感度解析を行った. なお，この 

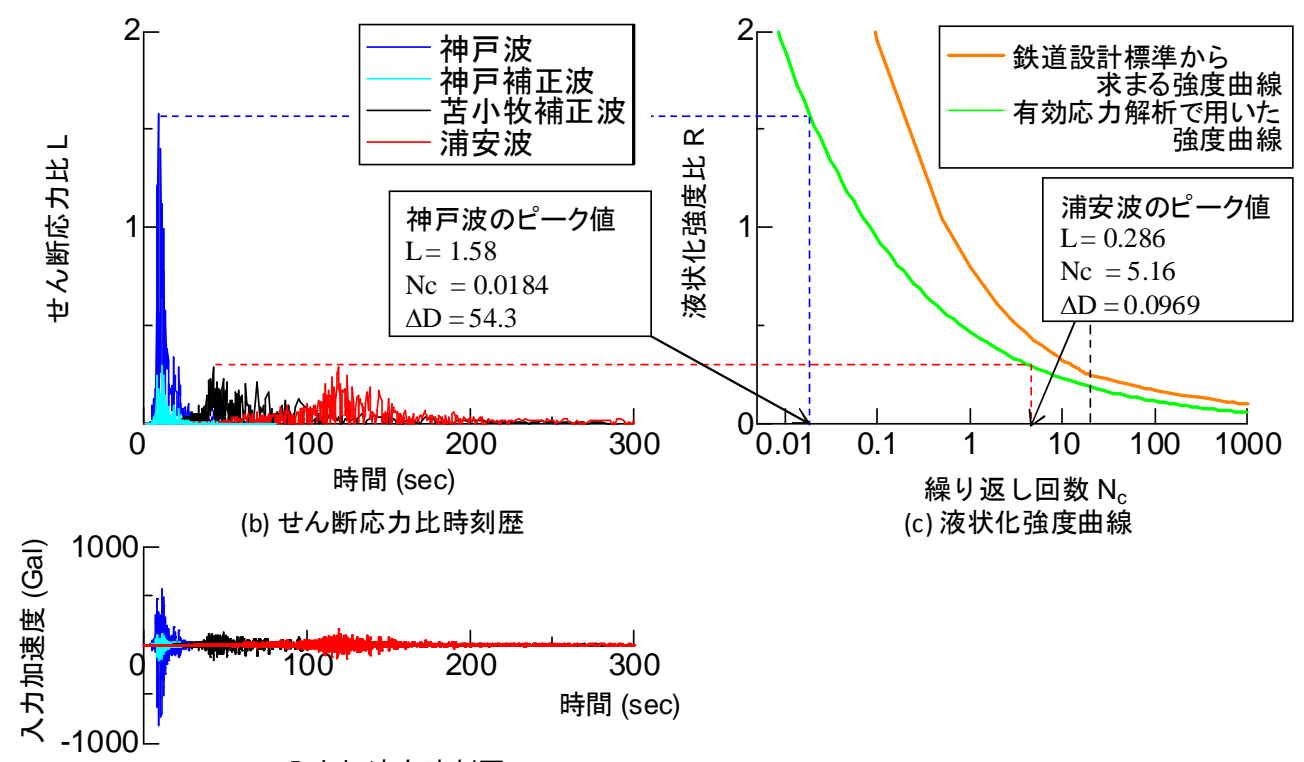

(c) 液状化強度曲線

(a) 入力加速度時刻歴

図-5 まさ土層(2における各地震動に対する入力加速度・せん断応力比時刻歴と 有効応力解析および累積損傷度法で用いた液状化強度比

表-5 有効応力解析に用いた液状化強度曲線を用いた 累積損傷度法による液状化判定結果

神戸波

\begin{tabular}{ccccccc}
\hline & $\mathrm{R}_{20}$ & $\mathrm{R}_{\mathrm{L}}$ & $\mathrm{R}_{\mathrm{L}} / \mathrm{R}_{20}$ & $\mathrm{~L}$ & $\mathrm{~F}_{\mathrm{L}}$ & $\Delta \mathrm{P}_{\mathrm{L}}$ \\
\hline \hline まさ士層(2) & 0.19 & 0.261 & 1.37 & 1.580 & 0.165 & 17.0 \\
まさ土層(3) & 0.19 & 0.259 & 1.36 & 1.557 & 0.166 & 14.7 \\
まさ土層(4) & 0.20 & 0.258 & 1.29 & 1.524 & 0.169 & 17.3 \\
\hline & & & & & $\mathrm{P}_{\mathrm{L}}=$ & 49.0 \\
\hline
\end{tabular}

神戸補正波

\begin{tabular}{ccccccc}
\hline & $\mathrm{R}_{20}$ & $\mathrm{R}_{\mathrm{L}}$ & $\mathrm{R}_{\mathrm{L}} / \mathrm{R}_{20}$ & $\mathrm{~L}$ & $\mathrm{~F}_{\mathrm{L}}$ & $\Delta \mathrm{P}_{\mathrm{L}}$ \\
\hline \hline まさ士層(2) & 0.19 & 0.261 & 1.37 & 0.302 & 0.863 & 2.80 \\
\hline まさ士層(3) & 0.19 & 0.259 & 1.36 & 0.298 & 0.871 & 2.28 \\
まさ士層(4) & 0.20 & 0.258 & 1.29 & 0.291 & 0.887 & 2.36 \\
\hline & & & & & $\mathrm{P}_{\mathrm{L}}=$ & 7.44 \\
\hline
\end{tabular}

苫小牧補正波

\begin{tabular}{ccccccc}
\hline & $\mathrm{R}_{20}$ & $\mathrm{R}_{\mathrm{L}}$ & $\mathrm{R}_{\mathrm{L}} / \mathrm{R}_{20}$ & $\mathrm{~L}$ & $\mathrm{~F}_{\mathrm{L}}$ & $\Delta \mathrm{P}_{\mathrm{L}}$ \\
\hline \hline まさ士層(2) & 0.19 & 0.191 & 1.01 & 0.286 & 0.667 & 6.79 \\
\hdashline まさ士層(3) & 0.19 & 0.192 & 1.01 & 0.273 & 0.703 & 5.25 \\
\hline まさ士層(4) & 0.20 & 0.203 & 1.01 & 0.254 & 0.802 & 4.12 \\
\hline & & & & & $\mathrm{P}_{\mathrm{L}}=$ & 16.2 \\
\hline
\end{tabular}

浦安波

\begin{tabular}{ccccccc}
\hline & $\mathrm{R}_{20}$ & $\mathrm{R}_{\mathrm{L}}$ & $\mathrm{R}_{\mathrm{L}} / \mathrm{R}_{20}$ & $\mathrm{~L}$ & $\mathrm{~F}_{\mathrm{L}}$ & $\Delta \mathrm{P}_{\mathrm{L}}$ \\
\hline \hline まさ士層(2) & 0.19 & 0.189 & 0.995 & 0.286 & 0.660 & 6.92 \\
\hline まさ士層(3) & 0.19 & 0.190 & 1.000 & 0.273 & 0.697 & 5.36 \\
まさ士層(4) & 0.20 & 0.203 & 1.015 & 0.254 & 0.800 & 4.16 \\
\hline & & & & & $\mathrm{P}_{\mathrm{L}}=$ & 16.4 \\
\hline
\end{tabular}

検討では，20回以下の繰返しに対する液状化強度の影響 を無視するため，20回以降の強度曲線の形状のみを変え て試算を行っている。したがって, 本来の液状化強度曲 線は繰返し回数に対して連続的に低下するが，今回の検 討では20回の繰返し回数を境に不連続となっている.こ
こでは浦安波および神戸波を例として判定を行った。 $\alpha=-0.23,-0.4,-0.6,-0.8$ の液状化強度曲線は図-4(c) に示す通 りである. 例えばせん断応力比 $\mathrm{L}=0.150$ 場合, $\alpha=-0.23$ で は $\mathrm{N}_{c}=180, \Delta \mathrm{D}=0.0055$ であるのに対して,$\alpha=-0.8$ とした場 合は $\mathrm{Nc}=37.6, \Delta \mathrm{D}=0.0279$ となり，損傷度 $\Delta \mathrm{D}$ として5倍程 度の差が生じることとなる.

表-4に累積損傷度法により夜状化判定結果をまとめた。 浦安波を入力した場合， $\alpha=-0.23,-0.4,-0.6,-0.8$ に対して $\mathrm{P}_{\mathrm{L}}$ でそれぞれ1.88, 9.59, 22.37, 34.50亡なり, 多繰り返し領 域の液状化強度曲線にかなり大きく影響を受けることが 分かる.したがって, 低加速度・長継続時間地震動に対 して累積損傷度法を適用する場合，多繰り返し領域の液 状化強度曲線を精度良く算定し，適切な $\alpha$ を設定する必 要があると言える.一方，神戸波の場合は $\mathrm{P}_{\mathrm{L}}=44.0,44.5$, 45.4，46.4と大きな違いは見られない.これは大きなせ 几断応力比に対する損傷度が圧倒的に大きく, 小さなせ ん断応力比の影響が相対的に小さくなるためである.

\section{（4）有効応力解析との時刻歴での比較}

ここまでの液状化判定に用いた液状化強度曲線は鉄道 設計標準の簡易算定式から求めたものを用いてきた。こ こでは, 有効応力解析の要素シミュレーションから得ら れる液状化強度曲線を用いた液状化判定結果と有効応力 解析結果を比較する. 図-5(a)〜 (c) に今回用いた4波の 加速度時刻歴，まさ士層(2)におけるせん断応力比，鉄道 標準から求まる液状化強度曲線と有効応力解析で用いた 液状化強度曲線をそれぞれまとめている. 有効応力解析 の液状化強度曲線を用いた場合の累積損傷度法による液 状化判定結果を表-5に示す。苫小牧補正波，浦安波に対 しては $\mathrm{P}_{\mathrm{L}}=16$ 程度と液状化する可能性の高い地盤と判定 

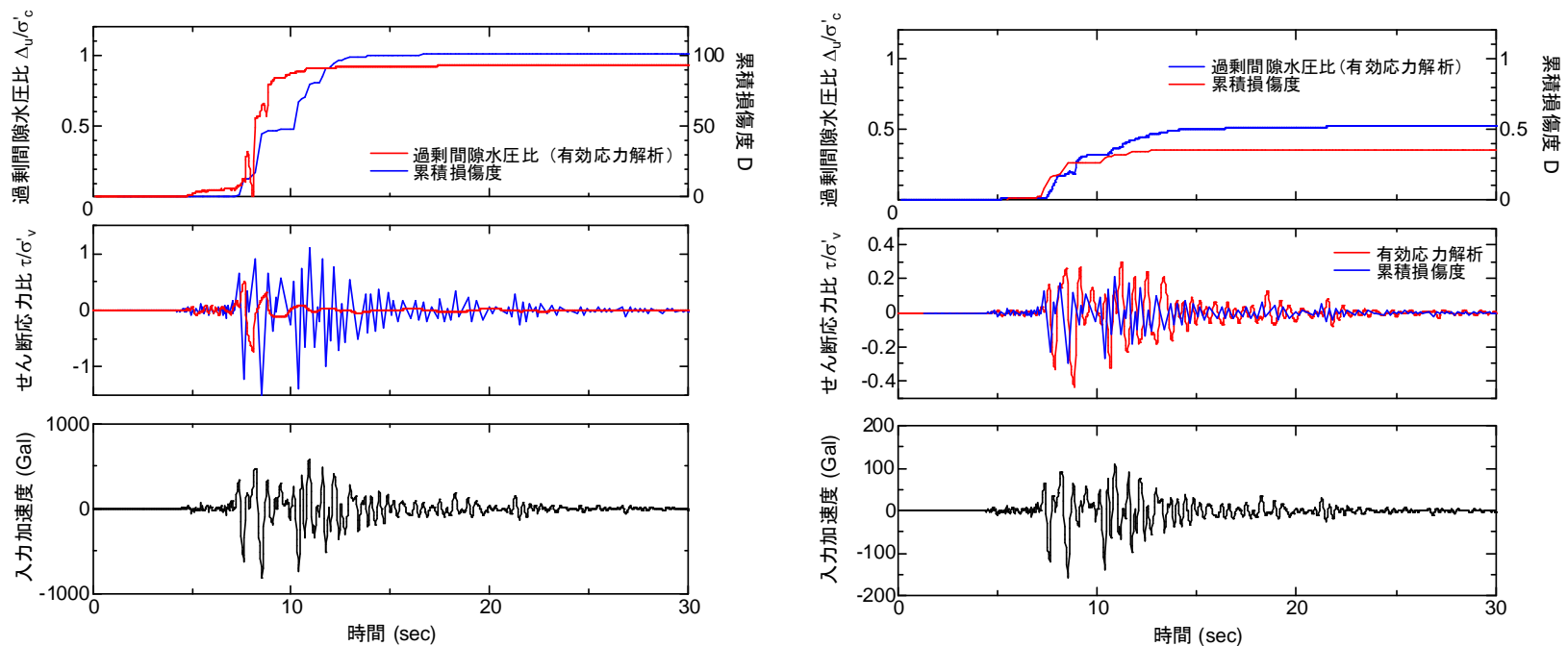

(a) 神戸波

(b) 神戸補正波

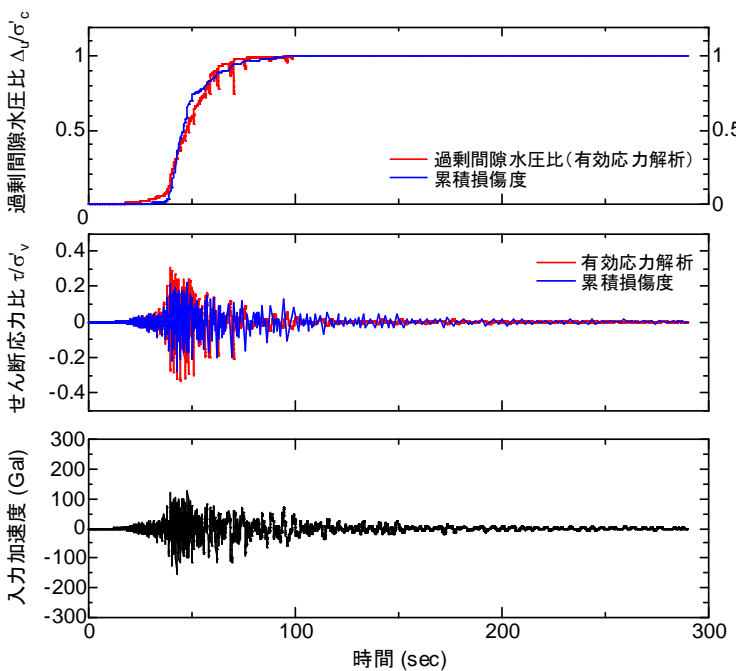

(c) 苫小牧補正波
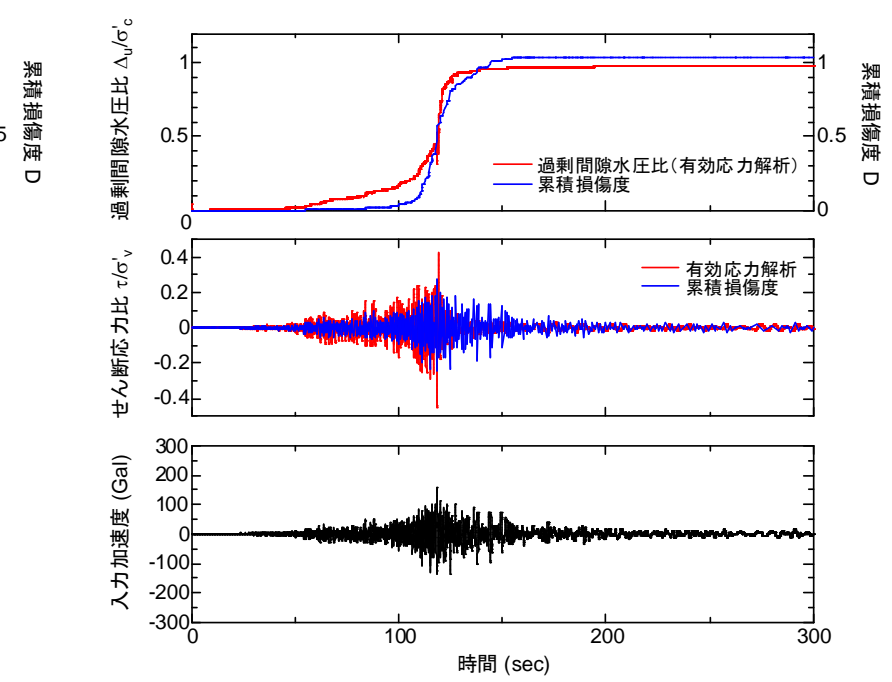

(d) 浦安波

図-6 有効応力解析と累積損傷度法によるまさ土層(2)の応答值の比較

されるようになる。しかしながら，神戸波に対しては $\mathrm{P}_{\mathrm{L}}=49$ であり，両者の液状化程度に大きな差があると判 定される.

図-6に有効応力解析から得られる過㮃間隙水圧比 $\Delta \mathrm{u} / \sigma_{\mathrm{c}}$ の時刻歴と累積損傷度法から得られる累積損傷度 Dの時刻歴，有効応力解析と累積損傷度法からそれぞれ 得られるせん断応力比 $\mathrm{L}\left(=\tau / \sigma_{\mathrm{v}}{ }^{\prime}\right)$ の時刻歴を示す。ここで 累積損傷度Dは過剰間隙水圧比 $\Delta \mathrm{u} / \sigma_{\mathrm{c}}$ をを表す指標と考え ることが出来る．低加速度の神戸補正波，苫小牧補正波， 浦安波の結果を見ると，累積損傷度法に用いたせん断応 力比は有効力解析結果より小さめの評価をしているもの の，傾向をよく捕らえている. また，その結果算定され る累積損傷度 $\mathrm{D}$ にいても，有効応力解析の過剰間隙水 圧比の上昇傾向をよく再現出来ている.

一方，神戸波を入力した場合のせん断応力比の時刻歴 に着目すると，有効応力解析の場合は 2 波目の忘答で大 きな過唾過激水圧が発生して地盤の岡性が低下するため,
それ以降のせん断応力はほとんど作用しない結果になっ ている．それに対して累積損傷度法では過剰間隙水圧の 上昇に伴う地盤の剛性低下をそもそも考慮していないた め，その傾向は追えない。しかしながら，累積損傷度法 においてもせん断応力比波列の2波目で D=13.1となり， 有効応力解析と同様に2波目で液状化に至ることを評価 出来ている。したがって，大振幅の地震動の場合，液状 化に至るまでの傾向はある程度再現できるものの，液状 化発生後のせん断応力比を過大に算定してしまい, 結果 的に大きな $\mathrm{P}_{\mathrm{L}}$ 与える可能性があると考えられる.

\section{5. まとめ}

本稿では，1995年兵庫県南部地震で著しい液状化が生 じた深江浜地盤を対象として有効応力解析を行い，地盤 の液状化に対する入力波の影響を考察した。また，累積 
損傷度法による液状化判定を行い, 有効応力解析との比 較を行うことで適用性を検討した，その結果，以下の結 論を得た.

1. 有効応力解析により, 低加速度・長継続時間地震動 によっても，大振幅の直下型地震と同等の液状化す る可能性があることを示した.

2. 累積損傷度法を用いて低加速度・長継続時間地震動 に対する液状化判定を行う場合, 多繰り返し部の液 状化強度曲線を精度良く評価する必要がある.

3. 鉄道標準で用いられている累積損傷度法によって, 液状化に至るまでのせん断応力比をある程度評価で き，過剩間隙水圧の上昇傾向も累積損傷度Dの増加 により概水評価できる．ただし，過剩間隙水圧の上 昇による剛性低下を考慮していないため，地震動初 期に大きな過剩間隙水圧が発生するような場合は, 過剩間隙水圧の上昇後のせん断応力を過大に算定し てしまい，過剩に液状化する判定を与えてしまう可 能性がある.

謝辞: 浦安波および苫小牧補正波は防災科学技術研究所 K-NETの強震記録を使用させていただきました.

\section{参考文献}

1）井澤 淳, 田上和也, 室野剛隆 : 地盤の液状化に及ぼす長継 続時間地震動の影響, 第46回地盤工学研究発表会, pp. 784 785, 2011.
2) 井澤 淳, 田上和也, 室野剛隆 : 地震動の長継続時間化・長 周期化が地盤の液状化に及ぼす影響, 土木学会第66回年次 講演会, pp. 365-366, 2011.

3) 東拓生, 田村敬一: 地震動波形の繰返し特性を考慮した液 状化強度評価法,土木技術資料39-9, pp. 50-55, 1997.

4) 東 拓生, 大塚久哲, 二宮嘉朗 : 砂質土の相対密度を考慮し た液状化強度曲線の定式化, 土木学会第49回年次学術講演 会, pp. 528-529, 1999.

5)八代和幸,杉戸真太,八嶋厚, 古本吉倫, 渦岡良介 : 震動継続 時間の影響を考慮した液状化危険度判定法について, 第27 回地震工学研究発表会, paperNo. 111 (CD-ROM), 2003.

6) 吉田 望, 大矢 陽介, 澤田 純男, 中村 晋 : 海溝型長継続時間 地震動に対する簡易液状化判定法の適用性, 日本地震工学 会論文集, Vol.9, No. 3, pp.28-47, 2003.

7) 鉄道構造物等設計標準・同解説 而震設計, 鉄道総合技術研 究所, 1999.

8) Towhata, I and Ishihara, K: Modeling soil behavior under principal stress axes rotation, Proc. of 5th International Conf. on Num Methods in Geomechanics, Vol. 1, pp. 523-530, 1985.

9) Iai, S. Matsunaga, M. and Kameoka, T.: Strain Space Plasticity Model for Cyclic Mobility, Soils and Foundations, Vol. 32, No. 2, pp. 1-15, 1992.

10) 三輪 滋, 池田隆明, 大岡 弘：1995 年兵庫県南部地震で液 状化した埋立て地盤に建つ鋼管杭基礎構造物の被害原因 と被害過程の検討, 日本地震工学会論文集, Vol. 4, No. 1, pp. 522, 2004.

11) 安田進, 吉川洋一, 牛島和子, 石川利明 : SI值を用いた液状 化予測手法,第28回土質工学研究発表会, pp. 1325-1328, 1993.

12）風間基樹,鈴木崇弘,柳澤栄司 : 地盤に入力された累積損失 エネルギーの評価法と液状化予測一の適用, 土木学会論文 集, No. 631/III-48, pp. 161-177, 1999.

(2011.12.13受付, 2012.2.28修正, 2012.3.6受理)

\title{
APPLICABILITY OF A ACCUMULATED DAMAGE PARAMETER METHOD ON SOIL LIQUEFACTION DUE TO SEVERAL EARTHQUAKES
}

\author{
Jun IZAWA, Kazuya TANOUE and Yoshitaka MURONO
}

Severe soil liquefaction due to long duration earthquake with low acceleration occurred at Tokyo Bay area in the 2011 off the Pacific coast of Tohoku Earthquake. This phenomenon clearly shows that soil liquefaction is affected by properties of input waves. This paper describes effect of wave properties of earthquake on liquefaction using Effective Stress analysis with some earthquakes. Analytical result showed that almost the same pore water pressure was observed due to both long duration earthquake with max acceleration of $150 \mathrm{Gal}$ and typical inland active fault earthquake with $891 \mathrm{Gal}$. Additionally, liquefaction potentials for each earthquake were evaluated by simple judgment with accumulated damage parameter, which is used for design of railway structures in Japan. As a result, it was found that accurate liquefaction resistance on large cyclic area is necessary to evaluate liquefaction potential due to long duration earthquake with low acceleration with simple judgment with accumulated damage parameter. 